\title{
Waste Glass in Porcelain
}

\author{
Saulo Roca Bragança*, Carlos Pérez Bergmann* \\ Laboratório de Cerâmicos \\ Av. Osvaldo Aranha, 99/s. 705, 90035-190 Porto Alegre - RS, Brazil
}

Received: May 21, 2004; Revised: October 9, 2004

\begin{abstract}
In this work, the feldspar used as a flux in typical porcelain was replaced by waste glass, and the resulting batch composition contained 50\% kaolin, 25\% quartz and 25\% waste glass. The properties of this porcelain with glass powder (GP) were compared to traditional porcelain (TP), which utilizes feldspar. The samples were fired at different temperatures, ranging from $1200{ }^{\circ} \mathrm{C}$ to $1400{ }^{\circ} \mathrm{C}$. Technical parameters, such as water absorption, modulus of rupture and $\mathrm{K}_{\mathrm{IC}}$, phase analysis by $\mathrm{XRD}$, and microstructure by $\mathrm{SEM}$ were analysed. The results indicated that the lower fracture toughness and MOR of GP is a consequence of the peculiar microstructure of this porcelain. The reduction in firing temperature and the use of a cheaper substitute for feldspar makes GP also an attractive economical alternative.
\end{abstract}

Keywords: porcelain, waste glass powder, strength, microstructure

\section{Introduction}

The choice of recyclable materials to replace conventional raw materials must be made carefully. The first step is to analyze the decomposition of the materials during the firing process due to the possible release of poisonous gases. This will probably eliminate the use of polymeric wastes such as tires, plastic bottles, etc. Inorganic materials may release heavy metals, fluorine and sulphur, which are very harmful to human health. An expensive alternative would be the treatment of the flue gas; however, these emissions can also cause serious damages on kiln refractory bricks. The gas emission levels, which will probably be even more restricted in the future, since they are controlled by environmental standards, must be considered too. The second step is to make sure that the ceramic product is inert during usage. This is especially important in the case of dinnerware, sanitary ware, and so on. Leaching can be a serious problem for floor tiles and roof tiles and also limits the choice of materials that can be used in body composition. Thus, the use of recycled colorless glass in the substitution of feldspar in the porcelain production, as proposed in this work, seems to be very suitable and environmentally safe.

As an initial criterion, and prior to make any experimental tests, the availability of recycled glass powder to the industry was checked. In Brazil, 890,000 tons of glass per year are produced; so, there is a huge potential of recycled glass powder availability. The total amount of glass collected in the cities for recycling exceeds 339,000 tons. This could be significantly increased by governmental incentives. The quantity of glass on the urban waste in the United States is $6.6 \%$ of the total weight, and is equivalent to 11.3 million tons of glass ${ }^{1}$.

The aim of this work was to evaluate the quality of the porcelain that can be made using glass powder. Samples were produced and fired in laboratory scale. Technical parameters such as water absorption, shrinkage, modulus of rupture, apparent porosity, density, weight loss and fracture toughness were determined. The phases present in the microstructure were evaluated using Scanning Electron Microscopy and X-ray diffractometry.

\section{Experimental}

Two batch compositions were tested in this work. One batch was composed of $25 \%$ wt. (\%) quartz, $50 \%$ wt. (\%) kaolin and $25 \%$ wt. (\%) feldspar (traditional porcelain - TP) and the other one was composed of 50\% wt. (\%) of kaolin, $25 \%$ wt. (\%) quartz and $25 \%$ wt. (\%) powdered soda-lime glass (glass powder porcelain - GP). Glass powder was used in the second batch replacing feldspar, which is normally used in traditional compositions. The main observations showed the role of the glass powder as a fluxing agent, which could be easily compared to TP. Table 1 shows the chemical analyses of the raw materials.

The glass powder was obtained from high transparency soda-lime glass pots and bottles without colouring oxides. The glass was ball milled and sieved to 270 mesh $(<53 \mu \mathrm{m})$. The crystalline phases in raw materials were determined by XRD. For kaolin, the results showed the presence of kaolinite $\left(\mathrm{Al}_{2} \mathrm{Si}_{2} \mathrm{O} 5(\mathrm{OH})_{4}\right)$ as the main crystalline phase, and muscovite $\left(\left(\mathrm{K} \mathrm{Al}_{2}\left(\mathrm{Al} \mathrm{Si}_{3} \mathrm{O}_{10}\right)(\mathrm{OH})_{2}\right)\right.$ plus illite $\left(\mathrm{K} \mathrm{Al}_{3} \mathrm{Si}_{3}\right.$ $\left.\mathrm{O}_{10}(\mathrm{OH})_{2}\right)$ as secondary crystalline phases. Kaolin was sieved to pass 325 mesh $(<45 \mu \mathrm{m})$. For feldspar, which was sieved to pass 270 mesh $(<53 \mu \mathrm{m})$, main crystalline phases were microcline $\left(\mathrm{KAlSi}_{3} \mathrm{O}_{8}\right)$ and albite $\left(\mathrm{NaAlSi}_{3} \mathrm{O}_{8}\right)$. Quartz was sieved to 325 mesh $(<45 \mu \mathrm{m})$, which is the particle size used in most Brazilian industries.

Table 1. Chemical composition of the raw materials (weight \%).

\begin{tabular}{lrrrr}
\hline & Kaolin & Feldspar & $\begin{array}{c}\text { Glass } \\
\text { Powder }\end{array}$ & Quartz \\
\hline $\mathrm{SiO}_{2}(\%)$ & 46.960 & 67.020 & 70.0 & 99.810 \\
$\mathrm{Al}_{2} \mathrm{O}_{3}(\%)$ & 38.050 & 19.220 & 2.0 & 0.120 \\
$\mathrm{Fe}_{2} \mathrm{O}_{3}(\%)$ & 0.460 & 0.190 & $<0.1$ & 0.080 \\
$\mathrm{MnO}(\%)$ & 0.008 & 0.007 & - & 0.002 \\
$\mathrm{CaO}(\%)$ & 0.020 & 0.060 & 6.0 & 0.010 \\
$\mathrm{Na} 2 \mathrm{O}(\%)$ & 0.030 & 3.750 & 20.0 & 0.030 \\
$\mathrm{~K}_{2} \mathrm{O}(\%)$ & 1.140 & 9.420 & - & 0.060 \\
$\mathrm{TiO}_{2}(\%)$ & 0.030 & 0.000 & $<0.1 \%$ & 0.073 \\
$\mathrm{P}_{2} \mathrm{O}_{5}(\%)$ & 0.108 & 0.035 & - & 0.020 \\
$\mathrm{LOI}(\%)$ & 13.200 & 0.300 & - & 0.100 \\
$\mathrm{Total}_{(\%)}$ & 99.990 & 100.000 & 98.0 & 99.900 \\
\hline
\end{tabular}


The raw materials selected were dry milled in a ball mill during 5 minutes in order to homogenize the mixture. The milling time necessary to achieve the optimum samples properties was previously determined. Eight percent of forming water was then added and the mixture sieved to 20 mesh prior to pressing. The dimensions of the samples were $8 \mathrm{~mm} \times 20 \mathrm{~mm} \times 60 \mathrm{~mm}$ for technical characterization and $8 \mathrm{~mm} \times 10 \mathrm{~mm} \times 60 \mathrm{~mm}$ for $\mathrm{K}_{\mathrm{IC}}$ and modulus of rupture (four points bending strength) determination. The samples were dried for 48 hours in air and then at $110^{\circ} \mathrm{C}$ for 24 hours in an electric furnace. No further change in weight occurred during this time, since the specimens were already dry. The dried pieces were then weighed and measured to obtain weight loss and dry density. The firing took place in an electric furnace at different temperatures between $1200{ }^{\circ} \mathrm{C}$ and $1420{ }^{\circ} \mathrm{C}$ with $150 \mathrm{~K} \cdot \mathrm{h}^{-1}$ heating rate and soaking time of 30 minutes. In order to obtain comparative results, samples with the same dry density $\left(1.80 \mathrm{~g} / \mathrm{cm}^{3}\right)$ were used in both batches. Such density was easily obtained for both formulations by changing the quantity of forming water and forming pressure.

\section{Results and Discussion}

Glass powder is a strong fluxing agent and has the capacity to form a lower melting point silicate. Therefore the firing temperature range was relatively narrow and different from that of traditional porcelain. Table 2 and Figure 1 show the technical characteristics of the fired pieces.

From the results shown in Table 2 and Figure 1, it is possible to consider the temperature of $1240{ }^{\circ} \mathrm{C}$ as the best firing temperature for glass porcelain and $1340{ }^{\circ} \mathrm{C}$ for traditional porcelain, considering linear shrinkage and bulk density values and a very low value of water absorption.

It can be seen in Figure 1 that the use of glass powder resulted in a lower firing temperature for GP, approximately $100^{\circ} \mathrm{C}$ lower than for TP, but within a shorter temperature range to fire GP. Table 2 shows that $0.39 \%$ of water absorption and $8.8 \%$ of linear shrinkage occurred for the $1240{ }^{\circ} \mathrm{C} \mathrm{GP}$ samples, while the $1340{ }^{\circ} \mathrm{C} \mathrm{TP}$ samples attained values of $0.34 \%$ water absorption and $12.2 \%$ of linear shrinkage. The lower firing temperature is an advantage for GP and confirms that the glass powder is a strong flux. But the short temperature range for firing GP indicates that more accurate temperature control is required during the firing process of this porcelain.

Microstructural analysis revealed which factors were more important to govern the final shrinkage and density of the pieces (Figure 2). The presence of a larger quantity of gas bubbles trapped in glassy phase compared with previous temperature had a stronger influence. TP samples had the same behaviour, (Figure 3), but in this case, bloating occurred at higher temperature and a larger firing range is possible for this composition.

The highest obtained densities were $2.28 \mathrm{~g} / \mathrm{cm}^{3}$ for GP and $2.48 \mathrm{~g} / \mathrm{cm}^{3}$ for TP at the best firing temperatures of $1240{ }^{\circ} \mathrm{C}$ and $1340{ }^{\circ} \mathrm{C}$, respectively. These were higher than the densities obtained at lower temperatures. The decrease in density values with increase in temperature - over firing - could be explained by the presence of trapped gas in the glassy phase as mentioned before. Thus, density, water absorption and apparent porosity all show the same tendency, regarding bloating, with increasing firing temperature. The higher bubble diameter on GP samples explains the lower density of this composition when compared to TP. The resulting microstructures due to firing at these temperatures $\left(1280^{\circ} \mathrm{C}\right.$ and $1420^{\circ} \mathrm{C}$, for $\mathrm{GP}$ and $\mathrm{TP}$, respectively) are characteristic of an over fired porcelain and the excess of heat explains the physical properties showed in Table 2.

The EDX analysis was taken simultaneously with microstructure observations, which supported the phases identification. The results of this analysis are shown in Figures 3 and 4 . Based on phase chemical analysis and phase morphology, which are well documented in literature ${ }^{2-6}$, it was possible to identify the phases named in Figure 4 and 5.

$\mathrm{XRD}$ analysis is showed in Figure 6, for the optimum firing temperature of each porcelain.

The main differences between the two porcelains are the presence of anorthite $\left(\mathrm{CaAl}_{2} \mathrm{Si}_{2} \mathrm{O}_{8}\right)$ in GP (Figure 6) and the presence

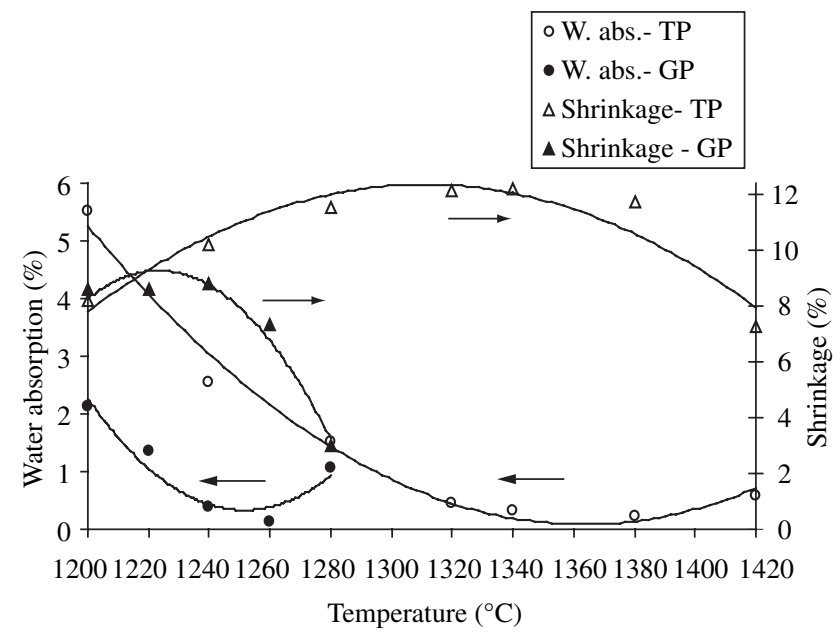

Figure 1. Water absorption and shrinkage as a function of peak temperature, showing the difference in optimum firing temperature between glass porcelain (GP) and traditional porcelain (TP).

Table 2. Water absorption, bulk density and shrinkage. Comparison between traditional porcelain (TP) and glass powder porcelain (GP) related to firing temperature.

\begin{tabular}{|c|c|c|c|c|c|c|}
\hline \multirow[b]{2}{*}{$\begin{array}{l}\text { Firing Temperature } \\
\qquad\left({ }^{\circ} \mathrm{C}\right)\end{array}$} & \multicolumn{3}{|c|}{ Traditional Porcelain } & \multicolumn{3}{|c|}{ Glass powder porcelain } \\
\hline & $\begin{array}{c}\text { Water absorption } \\
(\%)\end{array}$ & $\begin{array}{c}\text { Bulk density } \\
\left(\mathrm{g} / \mathrm{cm}^{3}\right)\end{array}$ & $\begin{array}{c}\text { Shrinkage } \\
(\%)\end{array}$ & $\begin{array}{c}\text { Water absorption } \\
(\%)\end{array}$ & $\begin{array}{l}\text { Bulk density } \\
\left(\mathrm{g} / \mathrm{cm}^{3}\right)\end{array}$ & $\begin{array}{c}\text { Shrinkage } \\
(\%)\end{array}$ \\
\hline 1200 & 5.52 & 2.22 & 8.2 & 2.13 & 2.25 & 8.6 \\
\hline 1220 & - & - & - & 1.35 & 2.26 & 8.6 \\
\hline 1240 & 2.55 & 2.35 & 10.2 & 0.39 & 2.28 & 8.8 \\
\hline 1260 & - & - & - & 0.15 & 2.23 & 7.3 \\
\hline 1280 & 1.53 & 2.41 & 11.5 & 1.06 & 1.84 & 3.0 \\
\hline 1320 & 0.46 & 2.47 & 12.2 & - & - & - \\
\hline 1340 & 0.34 & 2.48 & 12.2 & - & - & - \\
\hline 1380 & 0.22 & 2.42 & 11.7 & - & - & - \\
\hline 1420 & 0.59 & 2.16 & 7.2 & - & - & - \\
\hline
\end{tabular}


of secondary mullite in TP (Figure 5). The other crystalline phases, mullite $\left(2 \mathrm{SiO}_{2} \cdot 3 \mathrm{Al}_{2} \mathrm{O}_{3}\right)$ and quartz $\left(\mathrm{SiO}_{2}\right)$ were present in the structure for both formulations. The highest peak confirmed the existence of a greater amount of the mullite phase in TP (Figure 6). The peak height of quartz is approximately the same in the GP and TP samples, and it means that a significant amount of residual quartz did not suffer dissolution. Image analysis, performed according to the method suggested by Van Vlack ${ }^{7}$, was used to quantitatively evaluate phase composition. It confirmed that the amount of residual quartz was high, indicating approximately $20 \%$ of quartz for the traditional formulation and $16 \%$ of quartz for glass porcelain.

Anorthite is an unusual phase in porcelain. The crystallization of this phase within GP composition is a consequence of the presence of $\mathrm{CaO}$ in powdered soda-lime glass. Porcelain usually contains quartz, mullite and a glassy phase, as shown in Figures 5 and 6 for TP.

The importance of the glass phase composition, as well as the low

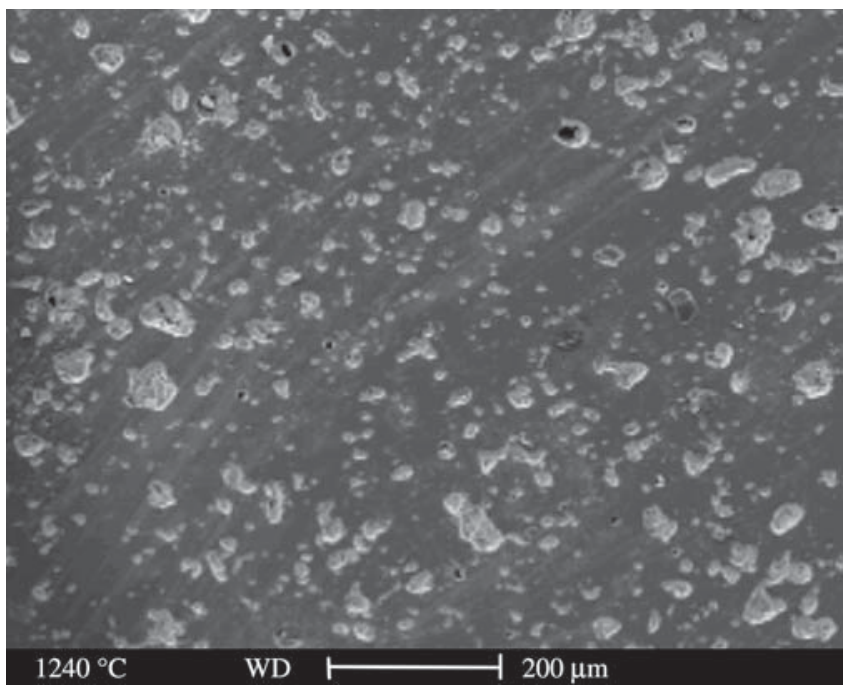

aluminum content in the melt, must be highlighted as a peculiarity of the use of soda-lime glass instead of feldspar. As a consequence of that, secondary mullite could not crystallize in the melt, as usually occurs with feldspar porcelain. However, the crystallization of secondary mullite from primary mullite could be occasionally observed, as shown in Figure 7.

\subsection{Fracture toughness and bending strength}

The mechanical behaviour of the ceramic bodies were analysed in this work in terms of fracture toughness and modulus of rupture (four points bending strength). Fracture toughness and fracture energy parameters and the critical flaw size were calculated according to Hübner ${ }^{8}$. The mean value of $\mathrm{K}_{\mathrm{IC}}$ was $1.6 \mathrm{MPa} \mathrm{m} \mathrm{m}^{1 / 2}$ for the TP samples and 1.3 $\mathrm{MPa} \mathrm{m}^{1 / 2}$ for GP samples (Tables 3 and 4). These are acceptable values for porcelain. Porcelain usually has a $\mathrm{K}_{\mathrm{IC}}$ range of between 1 and $2 \mathrm{MPa} \mathrm{m}^{1 / 29}$. The modulus of rupture (bending

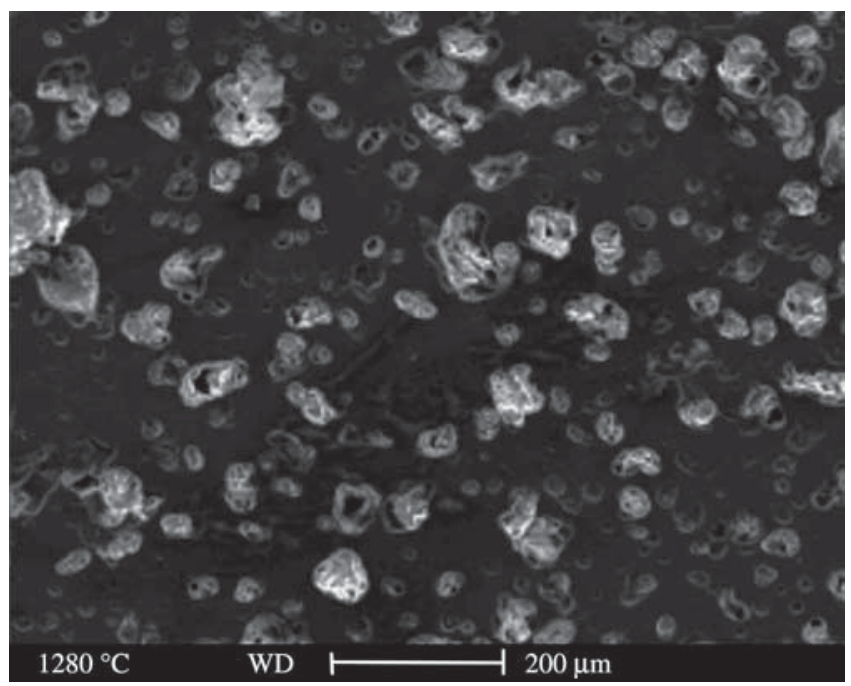

Figure 2. SEM photomicrograph of glass porcelain fired at $1240{ }^{\circ} \mathrm{C}$ and $1280^{\circ} \mathrm{C}$. Bloating as a consequence of temperature increasing.

Table 3. Modulus of rupture (MOR'), notch size ( $\left.\mathrm{c}^{\prime}\right)$, fracture toughness $\left(\mathrm{K}_{\mathrm{IC}}\right)$ and surface energy $(\gamma)$ of notched samples; bending strength (BS) and main flaw size (c) of non-notched samples. GP values after firing at $1240{ }^{\circ} \mathrm{C}$.

\begin{tabular}{|c|c|c|c|c|c|c|c|}
\hline \multirow[b]{2}{*}{ Samples } & \multicolumn{3}{|c|}{ Notched Samples } & \multirow[b]{2}{*}{$\begin{array}{c}\gamma \\
\left(\mathrm{J} / \mathrm{m}^{2}\right)\end{array}$} & \multicolumn{3}{|c|}{ Non - Notched Samples } \\
\hline & $\begin{array}{c}M O R^{\prime} \\
\left(\mathrm{N} / \mathrm{mm}^{2}\right)\end{array}$ & $\begin{array}{c}\mathrm{c}^{\prime} \\
(\mathrm{mm})\end{array}$ & 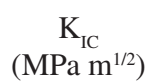 & & Samples & $\begin{array}{c}B S \\
\left(\mathrm{~N} / \mathrm{mm}^{2}\right)\end{array}$ & $\underset{(\mathrm{mm})}{\mathrm{c}}$ \\
\hline 1 & 25.0 & 0.946 & 1.43 & 13.0 & 1 & 53.4 & 0.159 \\
\hline 2 & 13.7 & 1.823 & 1.18 & 8.9 & 2 & 52.3 & 0.166 \\
\hline 3 & 21.8 & 1.253 & 1.45 & 13.5 & 3 & 51.0 & 0.173 \\
\hline 4 & 25.5 & 0.782 & 1.32 & 11.2 & 4 & 54.2 & 0.154 \\
\hline 5 & 22.5 & 1.332 & 1.56 & 15.5 & 5 & 53.3 & 0.158 \\
\hline 6 & 30.2 & 0.610 & 1.38 & 12.3 & 6 & 38.3 & 0.319 \\
\hline 7 & 17.5 & 1.180 & 1.12 & 8.1 & 7 & 41.3 & 0.271 \\
\hline 8 & 16.2 & 1.304 & 1.11 & 7.9 & 8 & 43.3 & 0.249 \\
\hline 9 & 22.7 & 0.788 & 1.18 & 8.9 & 9 & 45.3 & 0.223 \\
\hline 10 & 27.9 & 0.810 & 1.47 & 13.8 & 10 & 51.5 & 0.170 \\
\hline 11 & 20.9 & 1.177 & 1.34 & 11.6 & 11 & 45.7 & 0.219 \\
\hline 12 & 20.7 & 0.860 & 1.13 & 8.2 & 12 & 55.3 & 0.146 \\
\hline 13 & 14.1 & 1.682 & 1.15 & 8.5 & 13 & 48.5 & 0.195 \\
\hline- & - & - & - & - & 14 & 43.2 & 0.246 \\
\hline- & - & - & - & - & 15 & 55.1 & 0.147 \\
\hline mean & 21.4 & - & 1.29 & 10.7 & Mean & 48.8 & 0.200 \\
\hline
\end{tabular}

Remark: "c" "was obtained with a diamond disc. "c" results from theoretical calculations. 

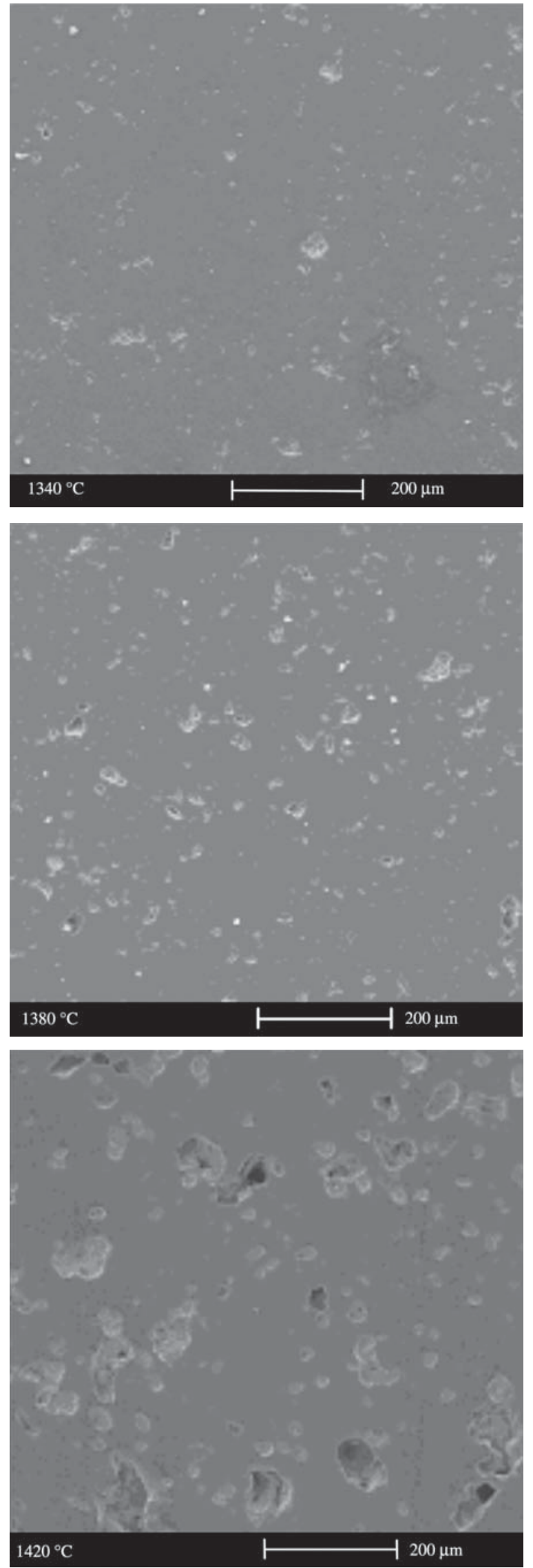

Figure 3. SEM photomicrograph of traditional porcelain fired at $1340{ }^{\circ} \mathrm{C}$, $1380^{\circ} \mathrm{C}$ and $1420^{\circ} \mathrm{C}$. Bloating was significant only at $1420{ }^{\circ} \mathrm{C}$.

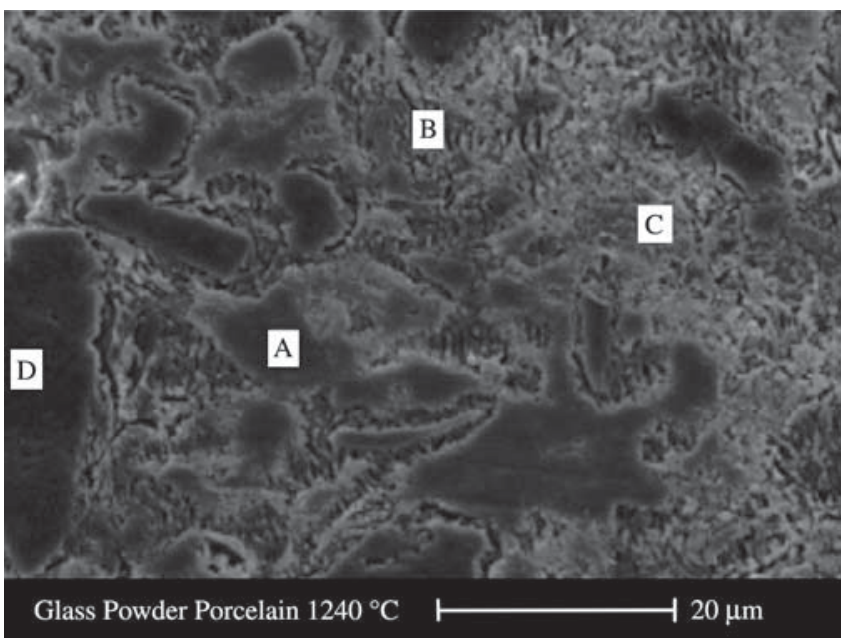

\begin{tabular}{c|lll}
\hline Letters & \multicolumn{1}{|c}{ Elements } & Main Phase & Secondary phases \\
\hline$A$ & $\mathrm{Si}, \mathrm{Al}, \mathrm{O}, \mathrm{Na}$ & Mullite & $\begin{array}{l}\text { Clayrelicts and } \\
\text { glass phase }\end{array}$ \\
$B C$ & $\mathrm{Si}, \mathrm{Al}, \mathrm{O}, \mathrm{Na}, \mathrm{Ca}$ & $\begin{array}{l}\text { Matrix } \\
\text { (glass phase) }\end{array}$ & $\begin{array}{l}\text { Clayrelicts, } \\
\text { mullite }\end{array}$ \\
$D$ & $\mathrm{Si}, \mathrm{O}$ & quartz & \\
\hline
\end{tabular}

Figure 4. EDX analysis of selected regions in SEM photomicrograph. Glass powder porcelain (GP) fired at $1240{ }^{\circ} \mathrm{C}$. Etched by $\mathrm{HF} 20 \%$ for 5 seconds.

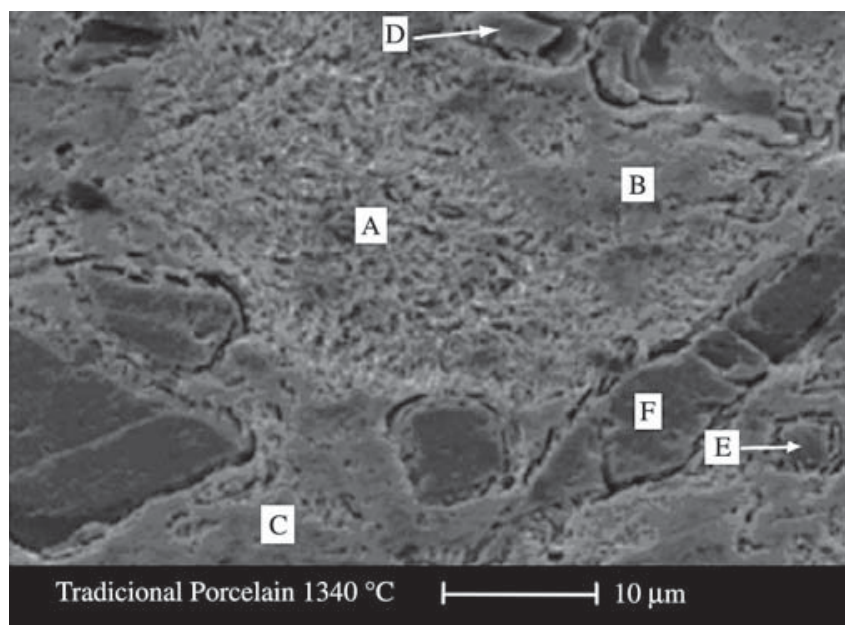

\begin{tabular}{c|lll}
\hline Letters & $\begin{array}{c}\text { Elementar } \\
\text { analysis }\end{array}$ & Main Phase & Secondary phases \\
\hline$A$ & $\mathrm{Si}, \mathrm{Al}, \mathrm{O}, \mathrm{K}, \mathrm{Na}$ & $\begin{array}{l}\text { secondary } \\
\text { Mullite }\end{array}$ & $\begin{array}{l}\text { Glass phase, } \\
\text { feldspar relicts }\end{array}$ \\
$B$ & $\mathrm{Si}, \mathrm{Al}, \mathrm{O}$ & primary mullite & Clayrelicts \\
$C$ & $\mathrm{Si}, \mathrm{Al}, \mathrm{O}$ & primary mullite & Clayrelicts \\
$D, E$ & $\mathrm{Si}, \mathrm{Al}, \mathrm{O}$ & clayrelict & \\
$F$ & $\mathrm{Si}, \mathrm{O}$ & quartz & \\
\hline
\end{tabular}

Figure 5. EDX analysis of selected regions in SEM photomicrograph. Traditional porcelain (TP) fired at $1340^{\circ} \mathrm{C}$. Etched by HF $20 \%$ for 5 seconds. 
strength) was high enough for porcelain, since they are suitable even for the porcelain stoneware (minimum strength $35 \mathrm{~N} / \mathrm{mm}^{2}$ according to the ISO 13006-B1a) ${ }^{10}$.

When comparing the values for the two porcelains it can be seen that TP has a higher $\mathrm{K}_{\mathrm{IC}}$ and a higher MOR. However, the mean crack length was almost similar $(200 \mu \mathrm{m})$ for both porcelains. Therefore, there is another factor besides crack length that has a strong influence on strength, which is responsible for the higher energy necessary to rupture TP. This factor is fracture energy $(\gamma)$, which has a value of $16.4 \mathrm{~J} / \mathrm{m}^{2}$ for TP and $10.7 \mathrm{~J} / \mathrm{m}^{2}$ for GP. Fracture energy is related to the energy consumed during crack propagation. This energy consumption is due to the presence of barriers that increase the crack path until the complete rupture of the sample. This phenomenon is widely explained in literature ${ }^{11,12}$. The presence of a higher content of crystalline phases, mainly quartz, primary and secondary mullite
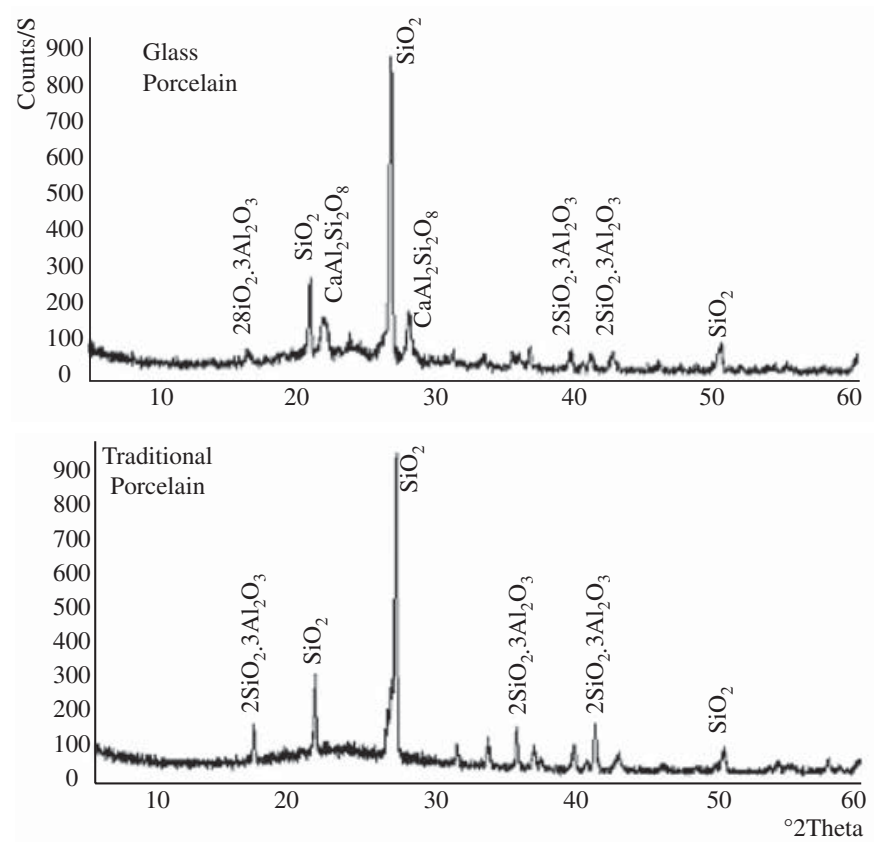

Figure 6. X-ray diffractogram of GP fired at $1240{ }^{\circ} \mathrm{C}$ and TP fired at $1340{ }^{\circ} \mathrm{C}$. (as indicated in the microstructure and X-ray diffractogram analysis), and the higher density of TP account for the higher strength of TP. The origin of this flaw is explained by the size of quartz particles used in the batch formulation. The stresses released due to large quartz particles and matrix thermal expansion mismatch cause this flaw. The size of the critical flaw is explained by the linking of the cracks originated around the quartz particles, as stated in the literature ${ }^{13-17}$ and showed here in Figure 8.

\section{Conclusions}

The comparison between glass porcelain (GP) and traditional porcelain (TP) shown that the use of recycled soda-lime glass powder as a fluxing agent replacing feldspar in a porcelain formulation is possible. Porcelain with excellent material properties was produced. Small differences in material properties were observed when compared to a traditional porcelain.

The lower firing temperature of $\mathrm{GP}\left(1240^{\circ} \mathrm{C}\right)$ than that of TP $\left(1340^{\circ} \mathrm{C}\right)$ was the most important advantage of GP. This could cer-

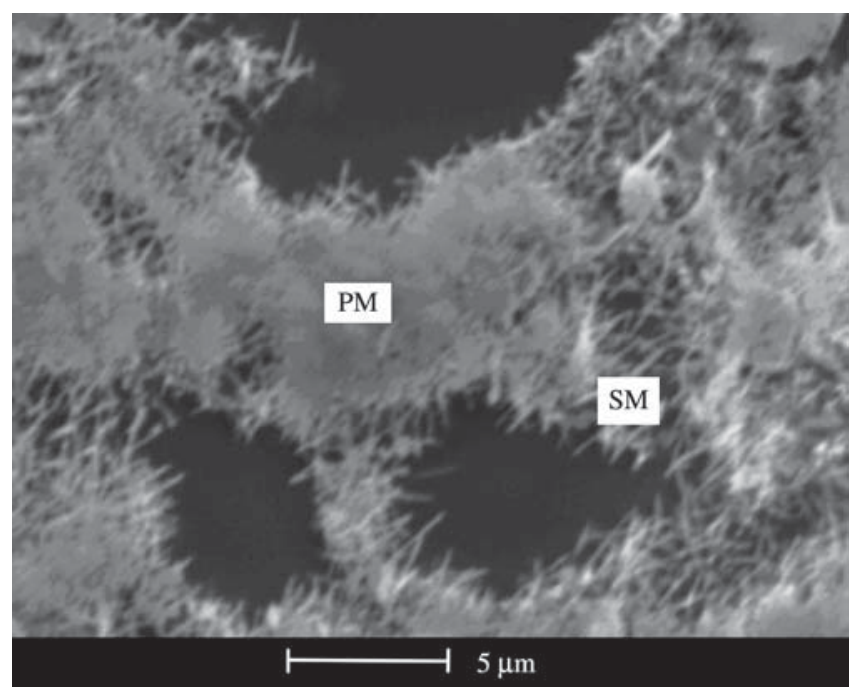

Figure 7. SEM photomicrographs of glass powder porcelain (GP) fired at $1240^{\circ} \mathrm{C}$. SM: secondary mullite. PM: primary mullite. Etched by HF $20 \%$ for 5 seconds.

Table 4. Modulus of rupture (MOR'), notch size ( $\left.\mathrm{c}^{\prime}\right)$, fracture toughness $\left(\mathrm{K}_{\mathrm{IC}}\right)$ and surface energy $(\gamma)$ of notched samples; bending strength (BS) and main flaw size (c) of non-notched samples. TP values after firing at $1340{ }^{\circ} \mathrm{C}$.

\begin{tabular}{|c|c|c|c|c|c|c|c|}
\hline \multirow[b]{2}{*}{ samples } & \multicolumn{3}{|c|}{ Notched Samples } & \multirow[b]{2}{*}{$\begin{array}{c}\gamma \\
\left(\mathrm{J} / \mathrm{m}^{2}\right)\end{array}$} & \multicolumn{3}{|c|}{ Non - Notched Samples } \\
\hline & $\begin{array}{c}M O R^{\prime} \\
\left(\mathrm{N} / \mathrm{mm}^{2}\right)\end{array}$ & $\begin{array}{c}\mathrm{c}^{\prime} \\
(\mathrm{mm})\end{array}$ & $\begin{array}{c}\mathrm{K}_{\mathrm{IC}} \\
\left(\mathrm{MPa} \mathrm{m}^{1 / 2}\right)\end{array}$ & & Samples & $\begin{array}{c}B S \\
\left(\mathrm{~N} / \mathrm{mm}^{2}\right)\end{array}$ & $\begin{array}{c}\mathrm{c} \\
(\mathrm{mm})\end{array}$ \\
\hline 1 & 15.4 & 1.87 & 1.51 & 14.5 & 1 & 52.4 & 0.257 \\
\hline 2 & 19.6 & 1.58 & 1.57 & 15.7 & 2 & 55.7 & 0.224 \\
\hline 3 & 28.1 & 1.03 & 1.71 & 18.6 & 3 & 61.8 & 0.180 \\
\hline 4 & 19.9 & 1.56 & 1.62 & 16.8 & 4 & 54.3 & 0.238 \\
\hline 5 & 19.7 & 1.45 & 1.51 & 14.6 & 5 & 62.3 & 0.177 \\
\hline 6 & 30.6 & 0.55 & 1.33 & 11.3 & 6 & 63.2 & 0.172 \\
\hline 7 & 22.4 & 1.19 & 1.49 & 14.2 & 7 & 66.1 & 0.156 \\
\hline 8 & 27.7 & 1.45 & 2.09 & 27.9 & 8 & 54.6 & 0.234 \\
\hline 9 & 18.9 & 1.54 & 1.50 & 14.4 & 9 & 61.4 & 0.182 \\
\hline 10 & 24.0 & 1.17 & 1.56 & 15.5 & - & - & - \\
\hline mean & 22.6 & - & 1.59 & 16.4 & Mean & 59.1 & 0.202 \\
\hline
\end{tabular}

Remark: "c" " was obtained with a diamond disc. "c" results from theoretical calculations. 


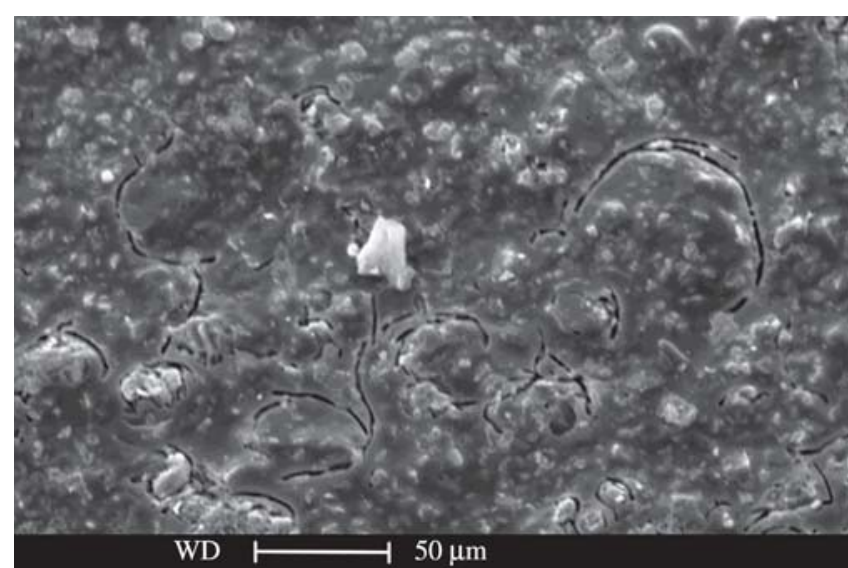

Figure 8. SEM photomicrograph of unpolished and non-etched glass porcelain surface, showing that crack bridging can occur due to the stresses released from large quartz particles.

tainly bring a cost reduction in the production process and make the use of glass powder an economical attractive alternative.

The curve of water absorption and shrinkage versus firing temperature indicated that glass powder behaved similarly to a strong flux. This has an advantageous effect of lowering the firing temperature, but decreases the temperature range for sintering. Glass porcelain demonstrated to be very susceptible to bloating, what had deleterious effects to glass porcelain properties in higher firing temperatures.

XRD analysis revealed the presence of anorthite in GP, as well as the mullite and quartz phases also found in TP porcelain. The crystallization of anorthite was a consequence of the calcium oxide within the soda-lime composition.

A fracture toughness $\left(\mathrm{K}_{\mathrm{IC}}\right)$ of $1.6 \mathrm{MPa} \mathrm{m}^{1 / 2}$ and a flexural strength of $59 \mathrm{~N} / \mathrm{mm}^{2}$ were obtained for the TP samples fired at $1340{ }^{\circ} \mathrm{C}$. For the GP samples fired at $1240{ }^{\circ} \mathrm{C} \mathrm{a} \mathrm{K}_{\mathrm{IC}}$ value of $1.3 \mathrm{MPa} \mathrm{m}^{1 / 2}$ and a MOR of $49 \mathrm{~N} / \mathrm{mm}^{2}$ were obtained. These results are good values for a fine ceramic. The lower fracture toughness and MOR of GP is a consequence of the peculiar microstructure of this porcelain.

\section{References}

1. Compromisso empresarial para a reciclagem (CEMPRE), 2004. Available from: URL: http//www.cempre.org.br

2. Kingery WD, Bowen HK, Uhlmann DR. Introduction to ceramics. $2^{\text {nd }}$ ed. New York: John Wiley \& Sons Publisher; 1976.

3. Schüller KH. Reactions between mullite and glassy phase in porcelains. Trans Br Ceram Soc. 1967; 63(2):103-106.

4. Carty MW, Senapati U. Porcelain - raw materials, processing, phase evolution, and mechanical behavior. J Am Ceram Soc. 1998; 81(1):3-20.

5. Iqbal Y, Lee W E J. Fired porcelain microstructures revisited. J Am Ceram Soc. 1999; 82(12): 3584-90.

6. Iqbal Y, Lee W E J. Microstructural evolution in triaxial porcelain. $J A m$ Ceram Soc. 2000; 83(12):3121-27.

7. Van Vlack L. Propriedades dos materiais cerâmicos. São Paulo, Brazil: Edgar Blücher Publisher; 1973.

8. Hübner H. Mechanical properties of advanced engineering ceramics. Tech Univ of Hamburg-Harburg. Hamburg (Germany): Ceramics Course Material; 2000.

9. Freiman SW. Fracture mechanics: Applications for whitewares. In: Henkes VE, Onada GY, Carty WM, editors. Science of whitewares. Westerville (Ohio): Am Ceram Soc; 1996. P. 293-304.

10. Biffi G. Il gres porcelanatto, manuale di fabbricazione e tecniche di impiego. Faenza (Italy): Faenza Editrice; 1997.

11. Wachtman JB. Mechanical properties of ceramics. New York: John Wiley \& Sons; 1996.

12. Davidge, RW. Mechanical behavior of ceramics. Cambridge University Press; 1979.

13. Warshaw SI, Seider R. Comparison of strenght of triaxial porcelains containing alumina and silica. J. Amer. Ceram. Soc. 1967; 50(7):337-42.

14. Oral MS. Fracture-initiating flaws in whitewares containing quartz. Trans J Br Ceram Soc. 1983; 82: 31-6.

15. Bragança SR, Bergmann CP. A view of whitewares mechanical strength and microstructure. Ceramics International. 2003: 29; 801-6.

16. Bragança SR. Desenvolvimento de uma cerâmica triaxial utilizando vidro como fundente e relação entre microestrutura e propriedades tecnológicas [Thesis]. Porto Alegre (RS). Federal University of Rio Grande do Sul; 2002.

17. Ece OI, Nakagawa Z. Bending strenght of porcelains. Ceramics International. 2002: 28; 131-140. 